\title{
Butternut: An Underused Resource in North America
}

M.E. O stry and P.M. Pijut

ADDITIONAL INDEX WORDS. Juglans cinerea, white walnut, Juglandaceae

Summary. Butternut (Juglanscinerea L.) has many fine qualities as a nut species, however, it has never been commercially important. Although the nut is very edible, only a few cultivars have been selected that have desirable nut size and cracking qualities. In the last 20 years there has been a dramatic decline in the number of butternut in native stands caused to a large extent by the lack of natural reproduction and a damaging canker disease. E vidence suggests that superior, disease resistant trees can be propagated and if isolated from areas where the disease is prevalent, may remain disease-free. It is important that the remaining genetic diversity within the species is maintained. Various butternut conservation practices and research projects to restore butternut populations are underway in the U nited States and C anada.

B

utternut, also known as white walnut, lemonnut, or oilnut, is a small- to medium-size tree, frequently 40 to $60 \mathrm{ft}$ ( 12 to $18 \mathrm{~m}$ ) tall and 12 to 24 inches ( 30 to $61 \mathrm{~cm}$ ) in diameter that seldom exceeds 75 years of age. Butternut is a shade intolerant species that may withstand competition from the sides, but will not survive shade from above. Butternut must be in the overstory to thrive (Rink, 1990).

The genus J uglans (J uglandaceae) consists of about 20 species referred to as walnuts and is divided into four taxonomic sections ( $M$ anning, 1978). Section Cardiocaryon consists of the species native to Asia; D i oscar yon contains one species ) . regia L. (Persian or English walnut), the most widely commercially cultivated species (M cG ranahan and L eslie, 1990); R hysocar yon is the section containing black walnut (J . nigra L.); and the section Trachycaryon in which butternut is the only member. Butternut hybridizes with J . regia and species in the section Cardiocaryon, but not with eastern black walnut. It has been suggested that butternut be included in section Cardiocaryon (Fjellstrom and Parfitt, 1994).

Butternut is seldom found growing in pure stands, but rather in association with several other tree species such as black cherry (Prunus serotina Ehrh.), American basswood (Tilia americana L.), white and northern red oak (Quercusalba L. and Q. rubra L .), black walnut (J . nigra L.), white ash (Fraxinusamericana L.), red and sugar maple (A cer rubrum L. and A. saccharum M arsh.), and A merican elm (UImusamericana L). 
It can however be locally abundant. I ts relatively short life span, lack of suitable conditions for regeneration, predation of seed by mammals, timber harvesting, and a lethal canker disease have dramatically reduced the number of butternuts throughout its range in $\mathrm{N}$ orth America. I ts widely scattered growth habit within stands, relatively soft wood, medium-sized kernel, and hard shell has prevented butternut from becoming a commercially important timber or nut species.

Butternut canker, caused by the fungus Sirococcus clavigignentijuglandacearum N .B. N air, Kostichka and Kuntz (N air et al., 1979) was first observed in 1967, and is now killing butternut throughout its native range in $\mathrm{N}$ orth America. The disease has killed up to $80 \%$ of the trees in some states and is threatening its survival as a viable species (O stry, 1997a, 1998a, 1998b).

\section{Native range}

Butternut commonly grows on rich loamy soils along streambanks in mixed hardwood forests as well as on well-drained, rocky soils of limestone origin. Thenative range of butternut is similar to black walnut, but it extends farther north and not as far south. It ranges from eastern $C$ anada west to $M$ innesota and as far south as Arkansas, Alabama, G eorgia, and M ississippi. Butternut has frequently been planted outside of its native range.

\section{Use}

Butternut is valued for its wood for furniture, paneling, specialty products, and carving, its flavorful nuts, wildlife mast, and for its contribution to forest diversity. I ts light tan heartwood is very workable with hand and power tools and it can be stained to resemble black walnut.

The nut is oily, sweet, and highly edible with an exceptionally good flavor; however, the kernels are generally difficult to extract (Bixby, 1919; Woodroof, 1979). Seed production begins on trees around 20 years of age, with good seed crops occurring every 2 to 3 years, based on seedling stands not grafted trees.

Early uses of butternut included the use of bark, roots, and husks for many medicinal purposes (Krochmal and Krochmal, 1982), and the use of the toxic bark thrown in small streams for stunning fish. An orange- or yellowbrown dye made from the husks was used by $\mathrm{N}$ ative Americans and also by the Confederate Army to dye Civil War uniforms giving rise to the name of butternutsforthetroops(Peattie, 1950). $\mathrm{N}$ ative Americans extracted oil from crushed butternuts by boiling them in water, and the sap of butternut has been used to make syrup (Goodell, 1984).

\section{Selected cultivars}

$M$ ore than 40 butternut cultivars have been described, but only a few have survived and are available as scionwood from individual collectors and germ plasm repositories. A few genotypes with good nut qualities (large size and ease of cracking) have been propagated and some of these are available from commercial nurseries (Ashworth, 1969; M illikan and Stefan, 1989; M illikan et al., 1990). N ut quality data for some selected butternut cultivars are reported in T able 1.

There are no known cultivars of butternut in commercial trade with proven resistance to butternut canker since most, if not all were selected for various tree and nut traits in the absence of the disease and no definitive test for resistance has been develo ped.

\section{Identification, reproduction, and propagation}

Juglans cinerea is considered to be one of themost winter-hardy of the Juglans species (U SDA $\mathrm{H}$ ardiness Zone 3 to 7). Butternut can be distinguished from black walnut by stems having chambered, chocolate-brown pith and a large, conspicuous leaf scar surmounted by a raised, downy pad. The butternut fruit is ovoid-oblong, sticky-pubescent, and averages 2 to 4 inches $(5$ to $10 \mathrm{~cm}$ ) in length. Fruits occur singly or in clusters of from two to five (Fig. 1). The nut is two-chambered, has a hard outer wall (pericarp), and exhibits eight prominent

Table 1. Selected cultivars of butternut and their nut quality data. ${ }^{z}$

\begin{tabular}{|c|c|c|c|c|}
\hline Cultivar & Origin & $\begin{array}{c}\text { Nut wt } \\
(\mathrm{g})\end{array}$ & $\begin{array}{c}\text { Kernel wt } \\
(\mathrm{g})\end{array}$ & $\begin{array}{c}\text { Percent } \\
\text { kernel }\end{array}$ \\
\hline Ayers & M ichigan & 9.2 & 2.16 & 23.48 \\
\hline Ayers & Grown in I owa & 7.0 & 1.38 & 19.71 \\
\hline Bear Creek & Washington (grown in I owa) & 11.5 & 1.86 & 16.32 \\
\hline Beckwith & O hio (grown in lowa) & 11.0 & 1.13 & 14.09 \\
\hline Booth & N ew York (grown in lowa) & 9.2 & 1.62 & 17.61 \\
\hline Buckley & lowa & 16.0 & 1.30 & 16.13 \\
\hline Buckley & Grown in Indiana & 27.0 & 3.90 & 17.10 \\
\hline Craxezy & M ichigan (grown in O hio) & 15.6 & 2.20 & 16.18 \\
\hline Creighton & Pennsylvania (grown in Iowa) & 9.0 & 1.68 & 18.67 \\
\hline Doud & Indiana & 16.0 & 2.92 & 18.38 \\
\hline George E Imer & N ew York (grown in Iowa) & 11.2 & 2.54 & 22.68 \\
\hline H errick & lowa & 20.8 & 3.20 & 15.38 \\
\hline $\mathrm{H}$ errington & Grown in I owa & 16.4 & 2.25 & 13.66 \\
\hline Kenworthy & M ichigan (grown in O hio) & 18.8 & 3.08 & 16.38 \\
\hline Painter & Pennsylvania (grown in Iowa) & 21.2 & 3.12 & 14.72 \\
\hline Rockville & Grown in Indiana & 14.4 & 2.22 & 15.42 \\
\hline Van Syckle & Grown in Indiana & 13.2 & 2.00 & 15.15 \\
\hline
\end{tabular}


ridges on the shell (four on the husk) (Fig. 2). Butternut bark is light gray, with shallow to moderately deep fissures and broad, flat ridges, developing a diamond-shape pattern in mature trees.

In spring, male flowers (catkins) preformed on the previousyear'swood emerge from small, scaly, cone-like buds, and the female flowers occur in two- to eight-flowered spikes borne on the current year's shoots (Dirr, 1990). M ale and female flowers mature at different times (Young and Young, 1992) ensuring out crossing in the population. Seeds of butternut, like most Ju glans species, have a dormant embryo, but dormancy can be broken by fall sowing or by moist (e.g. in sand), prechilling of seeds at 34 to $41^{\circ} \mathrm{F}\left(1\right.$ to $5^{\circ} \mathrm{C}$ ) for 3 to 4 months (Brinkman, 1974). Butternut seeds usually germinatein the spring following seedfall and germination is hypogeal (Rink, 1990). Young butternut trees can regenerate from stump sprouts.

Butternut is usually propagated by seed or by grafting onto black walnut rootstock because walnut rootstock is more readily available. Selected cultivars are vegetatively propagated by grafting onto seedling rootstocks. Propagation of butternut through rooting of cuttings has been reported (Pijut and Barker, 1999), but it is a time consuming process with variable success. I $\mathrm{n}$ vitro techniques offer an alternative for the propagation and preservation of existing butternut germ plasm (Pijut, 1993a, 1993b, 1997).

\section{Nursery production}

$\mathrm{N}$ urseries producing butternut seedlingsfollow similar guidelines and cultural practices routinely used for walnut production (J oneset al., 1998; Ramos, 1998; Schaefer, 1998). Butternuts grow best on well-drained loamy soil, and in a stunted form on shallow rocky sites and limestone flats (Schaefer, 1998). Complete site preparation and weed control is preferable for establishment and rapid growth. The nursery soil is best prepared the year before planting. The soil may be fumigated to control soilborne pests, and the application of fertilizer prior to planting will assure ad equate nutrient availability. Butternut fruit (nuts) mature and are harvested from September to $\mathrm{O}$ ctober. $\mathrm{N}$ uts can be har- vested from the trees with a shaker or allowed to fall naturally. The husksare removed (e.g. with a flail huller) and the nuts stratified as mentioned previously, for spring planting. Like walnut, butternut should be planted in s tu rather than transplanted (Schaefer, 1998). For intercropping and nut production, respectively, plant the trees at $40-\mathrm{ft}(12-\mathrm{m})$ spacing or $10-\mathrm{ft}(3-\mathrm{m})$ spacing in the rows (Schaefer, 1998). A $30 \times 30-\mathrm{ft}(9-\mathrm{m})$ orchard design is recommended for black walnuts(J ones et al., 1998). Mulch trees with sawdust or wood chips. Select cultivars of butternut are grafted onto seedling rootstock. $N$ ursery trees need to enter dormancy before being lifted. Seedlings can be placed in cold storage at 34 to $36^{\circ} \mathrm{F}$ ( 1 to $2{ }^{\circ} \mathrm{C}$ ) for several months. Care must be taken to keep the roots moist, but not wet, and prevent the stems from drying out during the storage period.

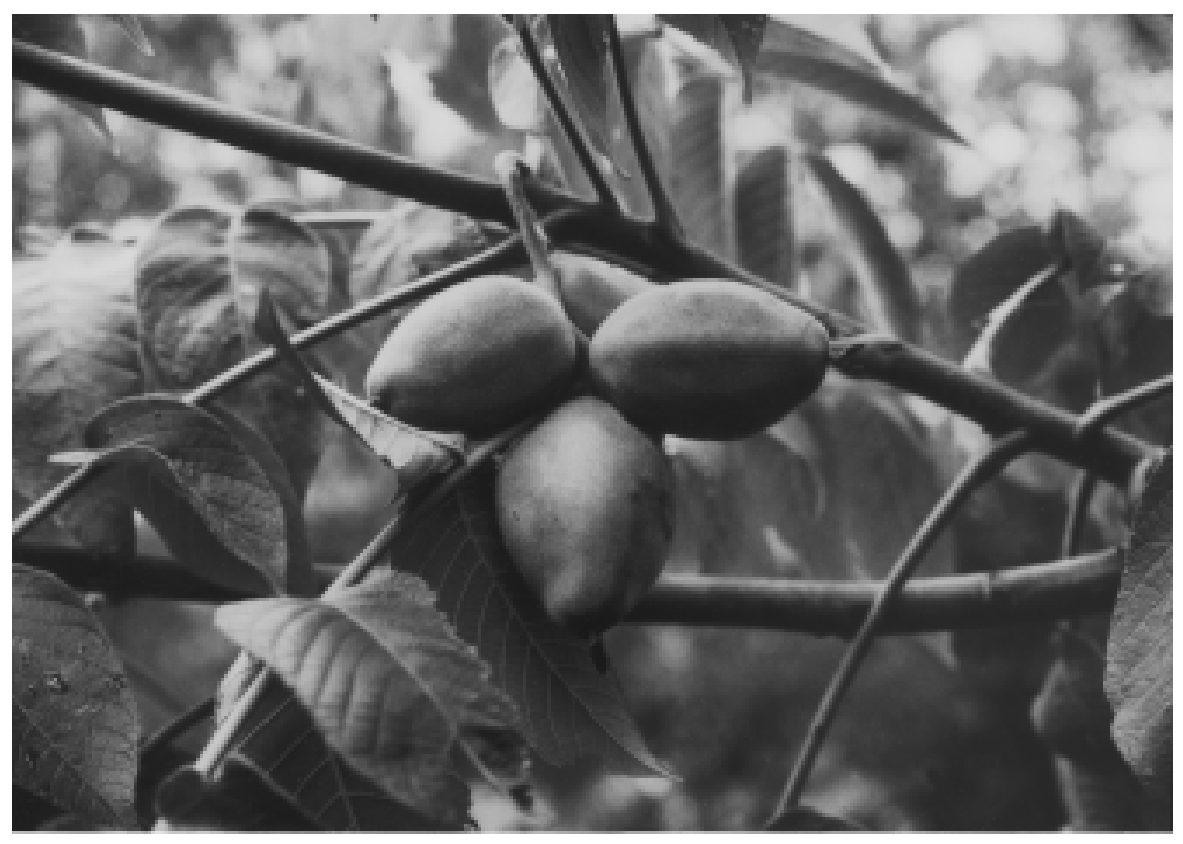

Fig. 1. Butternuts (J uglans cinerea) in their husks.

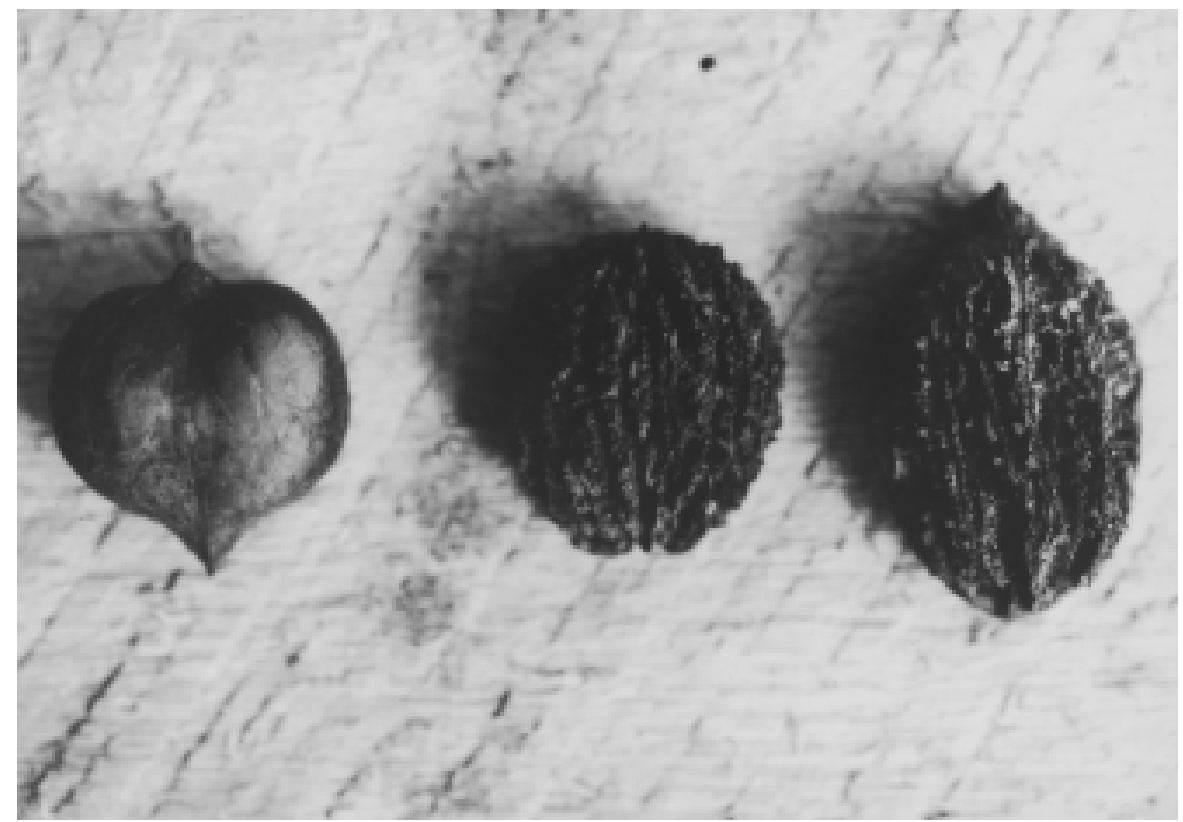

Fig. 2. Comparison of nuts with husks removed (left to right) heartnut (J uglans ailantifolia var. cordiformis), eastern black walnut (J. nigra), and butternut (J . cinerea). Butternut hybridizes with heartnut but not with eastern black walnut. 


\section{Damaging agents}

Butternut has similar insect pests to black walnut and other associated trees in its native range. The butternut curculio, Conotrachelus juglandis LeC onte (C orneil and Wilson, 1979), is the most serious, injuring young stems and fruit.

Themost seriousthreat to butternut is butternut canker, caused by what evidence suggests is an introduced fungus, S. clavigignentijuglandacearum (Furnier et al., 1999). Young cankers on branches and stems are elliptical, sunken areas, later developing an inky black center. M ultiple, perennial stem cankers often girdle and kill infected trees of all ages. The fungus has been found on branches of black walnut (O stry et al., 1997) and heartnut, J . ailantifolia var. cor diformis (M axim.) Rehd. (O stry, 1997b). Examination of walnutsexhibiting branch dieback but no cankers revealed hyphal pegsand hyaline, two-celled, fusiform conidia on affected branches (O stry et al., 1997) identical to those described for S. clavigignentijuglandacearum ( $\mathrm{N}$ air et al., 1979). I solations from symptomatic branches resulted in recovery of the fungus in pure culture. Branch dieback, but no cankerswerealso observed on heartnut (O stry, 1997b). H yphal pegs and conidia were present and the fungus wasisolated in pureculturesfrom symptomatic branches.

It is known that spores of $\mathrm{S}$. clavigignenti-juglandacearum are disseminated by rain splash and can travel in aerosols to adjacent trees where infection occurs on young branches in the upper crowns. Several insect species have been found associated with fungus spores on infected trees (Katovich and Ostry, 1998). Additional research is needed to determine if these insects could serve as vectors of the fungus, moving the pathogen over greater distances than rain splash spore dispersal. The fungus has also been found on the fruit of butternut and black walnut, causing lesions on the husks of both species (Innes, 1997).

\section{Current research}

Research at the USDA Forest Service-N orth Central Research Station is directed at determining the host range of the pathogen causing butternut canker, developing a reliable disease resistance screening technique, developing in vitro and various other clonal propagation techniques, and developing silvicultural strategies to regenerate and restore butternut on selected sites.

Although butternut is the only species significantly damaged by the canker disease, other Juglans species have been found to be susceptible in varying degrees to natural infection and to artificial inoculations. In addition, other hardwood species can be infected by $S$. clavigignentijuglandacearum in greenhouse tests. The fungus was reisolated from wood beyond the margin of wounds from inoculated pecan (Carya illinoensis Wangenh. K. Koch), shagbark hickory (Carya ovata Mill. K. Koch), black cherry (Prunusser otina), northern red oak (Q. rubra), white oak (Q. alba), and black oak (Q. velutina $L a m$.) (O stry, 1998b). It is important to determine if inconspicuous or latent infections of tree species other than Juglans can be a source of inoculum that could threaten new plantings. The evidencesuggesting that other J uglans species are susceptible to this fungus means that caution is advised to avoid introducing the pathogen into these plantings, either on planting stock or on seed.

\section{Conservation activities}

Butternut isin no immediatedanger of being lost as a species, however, many butternut populations are being killed by butternut canker or lost because of unfavorable stand conditions, advanced tree age, and the lack of reproduction. Genetic diversity is being lost within the species in many parts of its range. Special surveys to determinethehealth of butternut have been undertaken in the $U$ nited States and $C$ anada. Results have not been encouraging and butternut has been listed as rare or a species of special concern in many areas. R estrictions on harvest of healthy butternut on some public lands have been enacted, and silvicultural guidelines for managing butternut have been suggested ( 0 stry et al., 1994).

Several groupsin theU nited States and $C$ anada are using in situ and ex situ conservation methods to conserve potentially unique butternut genotypes to maintain thespecies. Education and technology transfer activities have been widely used to alert land managers and owners in the public and private sec- tors to the problem, and to elicit their assistance in research and conservation efforts to maintain butternut in the landscape.

$\mathrm{H}$ ealthy butternut growing among diseased trees may have resistance to the canker. Selected trees located throughout much of its range have been clonally propagated bygrafting and archived in replicated plantings in $\mathrm{M}$ innesota, W isconsin, Illinois, Vermont, and $\mathrm{N}$ ew York. These trees are being screened for resistance. Seed is being produced in the older plantings and these trees will be used for breeding if resistance to the disease is sufficient.

\section{Future outlook and recommendations}

Butternut isahighly desirablenut tree that merits consideration as a specialty species. It is very cold hardy relative to black walnut and is therefore especially well suited for northern regions. Thereare isolated areas where butternut canker has not been found and butternut selections exist in privatenurseries and collectionsfreefrom the disease. Since butternut is the major natural host for the pathogen, isolated plantings of butternut have a reasonable chance of remaining disease-free if the fungus is not introduced on planting material.

It may not be possible to completely restore butternut to all parts of its natural range. The possibility of successfully reintroducing butternut into areas where the disease has eliminated the original population is unknown. H owever, assuming the fungus is not common on other tree species and that insect vectors are not efficient in long-range spread of the pathogen, then the possibility of restoring trees in woodlots or growing butternut for nut production in orchards should be good. Promising selections of butternut collected throughout its native range should be propagated and conserved for future restoration use and potentially for breeding and nut production.

\section{Literature cited}

Ashworth, F.L. 1969. Butternuts, siebold japanese walnuts, and their hybrids, $p$. 224-231. In: R.A. Jaynes (ed.). $\mathrm{H}$ andbook of N orth American nut trees. N . N ut Growers Assn., Knoxville, Tenn.

Bish, C. 1990. Northern Nut Growers 
Association nut evaluation: $1989 \mathrm{~N}$ ut Crop. Annu. Rpt. N . N ut Growers Assn. 81:4755.

Bixby, W.G. 1919. The butternut and the japan walnut. Amer. N ut J. 10:76-83.

Brinkman, K.A. 1974. Juglans L. walnut, p. 454-459. In: C.S. Schopmeyer (tech. coord.). Seedsof woody plantsin theU nited States. Agr. H dbk. 450. U.S. D ept. Agr., For. Serv., Wash., D.C.

Corneil, J.A. and L.F. Wilson. 1979. Life history of the butternut curculio, C onotrachelus juglandis (C oleoptera: Curculionidae), in M ichigan. Great L akes Entomol. 12:13-15.

Dirr, M.A. 1990. M anual of woody landscape plants: their identification, ornamental characteristics, culture, propagation and uses. 4th ed. Stipes Publ. C o., Champaign, III.

Furnier, G.R., A.M . Stolz, R.M . M ustaphi, and M.E. O stry. 1999. Genetic evidence that butternut canker was recently introduced into North America. Can. J. Bot. 77(6):783-785.

Fjellstrom, R.G. and D.E. Parfitt. 1994. Wal nut (J uglansspp.) genetic diversity determined by restriction fragment length polymorphisms. Genome 37:690-700.

Goodell, E. 1984. Walnuts for the northeast. Arnoldia 44(1):3-19.

Innes, L. 1997. Sirococcus clavigignentijuglandacearum on butternut and black walnut fruit, p. 129-132. I n: G. L aflamme, J.A. Berube, and R.C. H amelin (eds.). Foliage, shoot, and stem diseases of trees. Proc. I ntl. U nion of For. Res. O rg. Working Party 7.02.02, Q uebec City, Canada.

Jones, J.E., R. Mueller, and J.W. Van Sambeek. 1998. Nut production handbook for eastern black walnut. SW M 0. Resource Conserv. D ev., Inc., Republic.

Katovich, S.A. and M .E. O stry. 1998. Insects asso ciated with butternut and butternut canker in M innesota and Wisconsin. Great Lakes Entomol. 31:97-108.

Krochmal, A. and C. Krochmal. 1982. $U$ ncultivated nuts of the $U$ nited States. U SDA For. Serv. Agr. Info. Bul. 450.

M anning, W.E. 1978. The classification within the Juglandaceae. Ann. Mo. Bot. Gardens 65:1058-1087.

M cD aniel, J.C. 1979. Other walnuts including butternut, heartnut, and hybrids, p. 98-110. In: R.A. J aynes (ed.). N ut tree culture in $\mathrm{N}$ orth America. N . N ut Growers Assn., $\mathrm{H}$ amden, Conn.

M CG ranahan, G. and C. Leslie. 1990. Walnuts (Juglans), p. 907-951. In: J.N . M ooreand J.R. Ballington (eds.). Genetic resources of temperate fruit and nut crops. vol. 2. Intl. Soc. H ort. Sci., Wageningen.

M illikan, D.F. and S. Stefan. 1983. Buttering up the butternut. Annu. Rpt. N. N ut Grow. Assn. 74:48-53.

M illikan, D.F. and S.J. Stefan. 1989. Current status of the butternut, Juglans cinerea L. Annu. Rpt. N. N ut Grow. Assn. 80:52-54.

M illikan, D .F., S.J . Stefan, and K.S. Rigert. 1990. Selection and preservation of butternut, Juglans cinerea L. Annu. Rpt. N. N ut Grow. Assn. 81:22-25.

Millikan, D.F., S.J. Stefan, and W.H. Shaffer, Jr. 1985. Butternuts worth propagating. Annu. Rpt. N. Nut Grow. Assn. 76:103-105.

Nair, V.M.G., C.J. Kostichka, and J.E. Kuntz. 1979. Si rococcus clavigignentijuglandacearum: An undescribed species causing canker on butternut. M ycologia 71:641-646.

O stry, M .E. 1997a. Butternut canker: H istory, biology, impact, and resistance, $p$. 192-199. In: J.W. Van Sambeek (ed.). Knowledge for the future of black walnut. Proc. 5th Black Walnut Symp., Springfield, M o. General Tech. Rpt. N C-191, U SD A For. Serv. N orth Central For. Expt. Sta., St. Paul, M inn.

O stry, M.E. 1997b. Si rococcus davigignenti-juglandacearum on heartnut (J uglansailantifolia var. cordiformis). Plant Dis. 81:1461.

O stry, M.E. 1998a. Butternut canker: A current example of the vulnerability of forest trees, p. 41-48. In: N.E. Carter (comp.). Proc. NE For. Pest Council Annu. $M$ tg., Fredericton, New Brunswick, Canada.

O stry, M.E. 1998b. Butternut canker in N orth America 1967-1997, p. 121-128.
In: G. Laflamme, J.A. Berube, and R.C. $\mathrm{H}$ amelin (eds.). Foliage, shoot, and stem diseases of trees. Proc. Intl. U nion of For. Res. O rg. Working Party 7.02.02, Q uebec C ity, Canada.

O stry, M .E., Katovich, S., and R.L. Anderson. 1997. First report of Sirococcus clavigignenti-juglandacearum on black walnut. Plant D is. 81:830.

O stry, M.E., M.E. M ielke, and D.D. Skilling. 1994. Butternut-strategies for managing athreatened tree. General Tech. Rpt. N C-165. U SDA For. Serv. North Cental For. Expt. Sta., St. Paul, M inn.

Peattie, D.C. 1950. Butternut, p. 119121. In: D.C. Peattie (ed.). A natural history of trees of eastern and central N orth America. H oughton M ifflin, Boston.

Pijut, P.M. 1993a. Somatic embryogenesis in butternut, Juglans cinerea. Can J. For. Res. 23:835-838.

Pijut, P.M . 1993b. R egeneration of J uglans cinerea through somatic embryogenesis. In Vitro Cell. Dev. Biol. 29A(3) Part II:69A.

Pijut, P.M. 1997. M icropropagation of Juglans cinerea L. (butternut), p. 345357. In: Y.P.S. Bajaj (ed.). Biotechnology in agriculture and forestry, vol. 39. H ightech and micropropagation V. SpringerVerlag, Berlin.

Pijut, P.M . and M .J . Barker. 1999. Propagation of Juglans cinerea $L$. (Butternut). H ortScience 34(3):458-459.

Ramos, D.E. (tech. ed.) 1998. Walnut production manual. U niv. Calif. Div. Agr. $\mathrm{N}$ atural Resources, $\mathrm{O}$ akland, Publ. 3373.

Rink, G. 1990. Juglanscinerea L. Butternut, p. 386-390. In: R.M. Burns and B.H. $\mathrm{H}$ onkala (tech. coords.). Silvics of N orth A merica. vol. 2. $\mathrm{H}$ ardwoods. U SD A For. Serv. Agr. H dbk. 654.

Schaefer, M . 1998. A nut growers' manual for eastern $O$ ntario and western Q uebec. E. Chapter Soc. O nt. N ut Growers, O ntario.

Woodroof, J.G. 1979. Tree nuts. AVI Publ. Co., Inc., Westport, Conn.

Young, J.A. C.G. Young. 1992. Seeds of woody plants in North America. $\mathrm{D}$ ioscorides Press, Portland, $O$ re. 